\title{
Effect of Biomixture Containing Spent Coffee Ground and Milled Egg-Shells on The Yield of Okra (Abelmoschus Esculentus Moench) and Soil Fertility under Greenhouse Conditions
}

\author{
Nghia K Nguyen ${ }^{\# 1}$, Bang V Nguyen ${ }^{\#}$, Sang H Do", Lang T Lam ${ }^{\#}$ \\ \# Department of Soil Science, College of Agriculture \& Applied Biology, Cantho University, Cantho City, Vietnam
}

E-mail:nknghia@ctu.edu.vn

\begin{abstract}
To evaluate the effect of biomixture including spent coffee ground and milled egg-shells (ratio of 10:2 (w/w)) on the yield of Okra (Abelmoschus esculentus Moench) and soil fertility, an experiment was conducted in the greenhouse for 3 months with four replicates for each treatment. The soil sample in this study was collected from the experimental farm of Cantho University. The biomixture was applied with 3 levels: 5, 10 and $15 \%(w / w)$. A commonly recommended inorganic fertilizer application rate for Okra was used as control treatment and $15 \%$ of used coffee ground as another treatment to study a single effect of used coffee ground on yield of Okra and soil fertility. Results showed that although the plan performance was much better in the control treatment, the highest yield of Okra was found in the treatments amended with 10 and 5\% of the biomixture and was 167 and 161 g/plant/pot, respectively. The yield was much higher in these two treatments than that in the control treatment. The appearance of Okra fruits in the amended biomixture treatments reached the standard quality for selling. Moreover, organic matter, $\mathrm{N}, \mathrm{P}, \mathrm{pH}, \mathrm{bacterial}$ and fungal cell counts in soils were enhanced considerably when amended with this biomixture. Five percent of the biomixture performed as the best treatment to enhance Okra yield in the greenhouse experiment.
\end{abstract}

Keywords - spent coffee ground; egg-shells; biomixture; Okra (Abelmoschus esculentus Moench); yield and soil fertility

\section{INTRODUCTION}

Coffee is one of the favourite drinks in many countries including Vietnam. It has several beneficial functions for human health's such as stimulating the nerve system, reducing daily stress and potential source of healthful antioxidants. With 500.000 ha of coffee plantation in total, Vietnam is the second largest coffee producing nation in all over the world [1]. Around 6.6 million tons of coffee are daily consumed and dumped as a bio waste from coffee processing companies, restaurants, small coffee shops and households to the environment [2]. This waste source is mainly considered as a dirty waste by most of people [3]. Actually, spent coffee ground can be recycled to become many by-products which can have many useful applications in agriculture and environment such as a source of bioenergy [4], animal feeds and organic fertilizer for plants and soil [5], [6] and organic subtracts for mushroom cultivation [7]. Large portion of spent coffee ground has currently been treated by burning. This causes a big emission of $\mathrm{CO}_{2}$ into the atmosphere and contributes into the global warming issue. Therefore, novel or innovative techniques which are applied efficiently to recycle spent coffee ground to valuable by-products for the social community and environment are very necessary and needed to be considered [8], [9]. Use of spent coffee ground as organic and bio fertilizer for plants and soil amendment as well is one of the most common recycling approaches. Although studies in recycling of spent coffee ground as organic material for plants and soils to reduce the environmental problem have just started recently, some outstanding results have been obtained in the aspects of crop yield increase, stress resistance, agricultural product quality and soil improvement [10], [11]. Besides spent coffee ground, egg shell is another waste source from live stock, animal husbandry and manufactured egg product activities being recycled as a source of fertilizer for plants and soils. The chemical composition of egg shells includes $\mathrm{N}$ $(0,00-1,16 \%), \mathrm{P}(0,07-0,18 \%), \mathrm{K}(0,08-0,10 \%)$, Ca $(28,0-$ $39,1)$ và $\mathrm{Mg}(0,16-0,41 \%)$ and especially amount of calcium carbonate in egg shells is very high, and varies from $94-97 \%$ of the total mass. In the USA every year, about 120,000 tons of egg shells are released into the landfill. This means that a large amount of plant nutrients and soil conditioner are wasted daily. However, there is no reported data regarding of daily wasted egg shell amount for Vietnam. Thus, recycling of egg shells to become fertilizer for plants and soils is very necessary [12]. In Vietnam, study in recycling of spent coffee ground as bio-organic fertilizer for plants and 
soils has never been conducted before. Therefore, the objective of this study was (1) to evaluate the effect of spent coffee ground and egg shells mixture on the plant performance and yield of okra under the greenhouse conditions and (2) to examine the influence of this mixture on some selected soil chemical and microbiological characteristics.

\section{MATERIALS AND METHODS}

\section{A. Soil Sample}

Soil sample, collected at the experimental farm of the college of Agriculture \& Applied Biology, Cantho University, Vietnam, was alluvial soil (Fluvisols). Soil sample was taken from 4 different points at the depth of 0-20 $\mathrm{cm}$ in the same sampling site, then all soil samples were combined together to become a unique sample. This sample was carried to the laboratory and air-dried at room temperature. Prior to take an aliquot for analysis of some soil chemical and biological properties, the soil sample was sieved through the $2 \mathrm{~mm}$ mesh sieve and ultimately homogenized. Each PE experimental pot with a size of 20 $\mathrm{cm}$ of height x $20 \mathrm{~cm}$ of weight contained $5 \mathrm{~kg}$ sieved soil (dry weigh). Some soil chemical characteristics of studied soil were presented in Table 1.

TABLE I

SOME CHEMICAL CHARACTERISTICS OF SPENT COFFEE GROUND, MILLED EGG-SHELLS AND SOIL SAMPLE.

\begin{tabular}{|l|c|c|c|c|c|r|}
\hline Materials & $\begin{array}{c}\text { pH- } \\
\mathbf{H}_{\mathbf{2}} \mathbf{O} \\
\mathbf{( 1 : 2 . 5 )}\end{array}$ & $\begin{array}{c}\text { EC } \\
(\mathbf{m S} / \mathbf{c} \\
\mathbf{m})\end{array}$ & $\begin{array}{c}\mathbf{O M} \\
\mathbf{( \% )}\end{array}$ & $\begin{array}{c}\text { Total } \\
\mathbf{N} \\
(\boldsymbol{\%})\end{array}$ & $\begin{array}{c}\text { Total } \\
\mathbf{P}(\boldsymbol{\%})\end{array}$ & $\begin{array}{c}\text { Total } \\
\mathbf{K}(\boldsymbol{\%})\end{array}$ \\
\hline $\begin{array}{l}\text { Spent } \\
\text { coffee } \\
\text { ground }\end{array}$ & 5.90 & 7.40 & 62.60 & 2.40 & 0.47 & 0.94 \\
\hline Egg-shells & 8.85 & 4.16 & 3.27 & 0.75 & 0.24 & 1.36 \\
\hline Soil & 6.80 & 1.50 & 2.49 & 0.24 & 0.19 & 1.26 \\
\hline
\end{tabular}

\section{B. Spent Coffee Ground}

Fresh spent coffee grounds were collected from several coffee shops in Xuan Khanh Ward, Ninh Kieu District, Can Tho City, Vietnam. Then, the coffee grounds were mixed together to become a large and unique sample, thereby taking a small aliquot to determine chemical properties of spent coffee grounds. Some chemical properties of spent coffee ground were presented in Table 1.

\section{Egg-Shells}

Egg-shells were collected from several bread selling vehicles in Xuan Khanh Ward, Ninh Kieu District, Can Tho City, Vietnam. After collecting egg-shells were rinsed with tape water and then dried continuously under the sunshine for 2 days, then the egg-shells were finely milled by mortar and pestle and mixed well. Ultimately, taking a small aliquot of egg-shells to analysis chemical properties. Some chemical characteristics of milled egg-shells were presented in Table 1.

\section{Seed}

High production Okra variety, NT1 was purchased from Trang Nong Seed Company.

\section{E. Pot Experiment}

The experiment was conducted in the greenhouse of Soil Science Department, College of Agriculture and Applied Biology, Can Tho University, Vietnam with 5 treatments and 4 replicates for each treatment (one pot was corresponded with one treatment replicate). The treatments were listed as follows:

T1: $15 \%$ biomixture

T2: $10 \%$ biomixture

T3: $5 \%$ biomixture

T4: $15 \%$ spent coffee ground

T5: recommended chemical fertilizer $(14-3.2-12 \mathrm{~kg}$ ) (per $1.000 \mathrm{~m}^{2}$ )

A biomixture contained spent coffee ground and milled egg-shells with a ratio 10:2, respectively (dry weight) for the combination formulation. The recommended inorganic fertilizer application rate for Okra was used as a control treatment. The inorganic fertilizer dose was divided into 4 application times: in the $1^{\text {st }}$ application time entire $\mathrm{P}, 1 / 4 \mathrm{~N}$ and $1 / 4 \mathrm{~K}$ were introduced and this application time was performed at day 0 ; in the $2^{\text {nd }}, 3^{\text {rd }}$ and $4^{\text {th }}$ application times $1 / 4$ $\mathrm{N}$ and $1 / 4 \mathrm{~K}$ were applied at day 15, 30 and 45 after sowing, respectively. The biomixture of coffee ground and eggshells was amended for each treatment basing on the dry weight of the soil in each pot $(\mathrm{w} / \mathrm{w})$. Okra seedlings were sown after 10 days of organic material application. Each pot was sown with 4 seedlings, and then ultimately seedlings were thinned to 1 plant per experimental pot. The experiment was lasted for 95 days in total. The main purpose of including the treatment (T1) and treatment 4 (T4) in this study was to assess whether the spent coffee ground and a mixture containing of spent coffee ground and egg-shells may cause any plant growth inhibition or phytotoxicity effect when they were applied with a high dose.

\section{F. Agronomic and Soil Parameters}

The agronomic parameters of Okra such as plant height and number of leaves per plant were monitored and measured at 15, 30, 45 and 60 days after sowing. The diameter of Okra trunk was recorded at 45 and 60 days after sowing. Okra fruits were collected at the right time when they were still young enough for consumption and total fruit weight per pot was recorded. Soil of each pot was sampled at $0,10,45$ and 95 days after conducting the experiment to measure soil $\mathrm{pH}, \mathrm{EC}$ (extracted with distilled water in a ratio of 1:2.5 (soil:water) then measured with $\mathrm{pH}$ meter), the total bacteria and fungi numbers in the soil (dilution method and cell counting according to [13]). Soil chemical parameters such as organic matter (Walkley-Black method), total nitrogen (Kjeldahl method), total phosphorus (digestion with concentrated $\mathrm{H}_{2} \mathrm{SO}_{4}$, phosphomolybdate complex formation and samples were measured on colormetric spectrophotometer) and total potassium (digestion with concentrated $\mathrm{H}_{2} \mathrm{SO}_{4}$, then determined by spectrophotometer) were analyzed. One soil sample for each treatment which was combined from 4 replicates at the end of the experiment was used for soil chemical parameter determination. 


\section{G. Data Analysis}

All data were collacted, synthesized and calculated by using Excel software. The Minitab 16.2 statistical software package was used to perform the ANOVA test.

\section{RESULT AND DISCUSSION}

\section{A. Chemical Composition of Spent Coffee Ground, Egg- Shells and Soil Sample}

As presented in Table 1 the chemical compositions of spent coffee ground, egg-shells and soil were widely varied. For fresh spent coffee ground, high level of nutrition was recorded, especially for nitrogen and organic matter contents, $2,4 \%$ and $62,6 \%$, respectively. $\mathrm{pH}$ of this material was slightly neutral $(5,90)$. Nutrient facts of spent coffee ground was similar to that of the compost fertilizer made from sugarcane filter cake [14]. This indicated that it was a good material to be applied for many kind crops as an organic fertilizer and that a potential of using this material to produce bio-fertilizer for crops is very high. Meanwhile, soil samples had also a neutral $\mathrm{pH}(6,80)$ and low nutrient values of organic matter, total nitrogen, phosphorus and potassium whereas the $\mathrm{pH}$ and $\mathrm{EC}$ value of egg-shell material were quite high, 8,85 and $4,16 \mathrm{mS} / \mathrm{cm}$, respectively. Other nutrient values including total nitrogen, phosphorus and potassium in egg-shells were low.

\section{B. Affect of Biomixture Contanining Spent Coffee Ground and Egg-Shells on Some Selected Soil Chemical and Microbiological Characteristics}

The entire document should be in Times New Roman or Times font. Type 3 fonts must not be used. Other font types may be used if needed for special purposes. Recommended font sizes are shown in Table 1.

\section{1) Soil Chemical Characteristics:}

Results of fluctuation in soil $\mathrm{pH}$ and $\mathrm{EC}$ values were showed in Fig. 1. $\mathrm{pH}$ values tended to be stable during experimental time in all treatments, except T5 (recommended inorganic fertilizer) and T4 (applying 15\% spent coffee ground) which had a decrease in soil $\mathrm{pH}$. At day 95, the lowest soil $\mathrm{pH}$ was found in $\mathrm{T} 4(\mathrm{pH}=6,0)$ and followed by $\mathrm{T} 5(\mathrm{pH}=6.4) . \mathrm{pH}$ values in these two treatments were significantly lower than that in the three remained treatments ( $\mathrm{T} 1, \mathrm{~T} 2$ and $\mathrm{T} 3$ ) amended with biomixture containing spent coffee ground and egg-shells (Fig. 1A). A decrease of soil $\mathrm{pH}$ during experimental time was one of the factors resulting in reducing Okra yield in these two treatments. In sum, applying biomixture including coffee ground and egg-shells did not cause any reduction of soil $\mathrm{pH}$.

Soil EC in all treatments tended to be increased slightly after 10 days of experiment, then felt sharply until at the end of the experiment. Overall, soil EC of all treatments was still in the optimal threshold for crop growth. At day 95, the highest EC was recorded by the T1 (15\% biomixture) while the lowest soil EC was recorded in T5 and T4 (Fig. 1B). This result indicated that biomixture including spent coffee ground and egg-shells could support an available nutrient source for plant uptake, consequently, crop yield increased. Thus, applying biomixture containing spent coffee ground and egg-shells not only makes no increase of saline and acidic soil, but also provide an available nutrient source for crops to increase the yield.

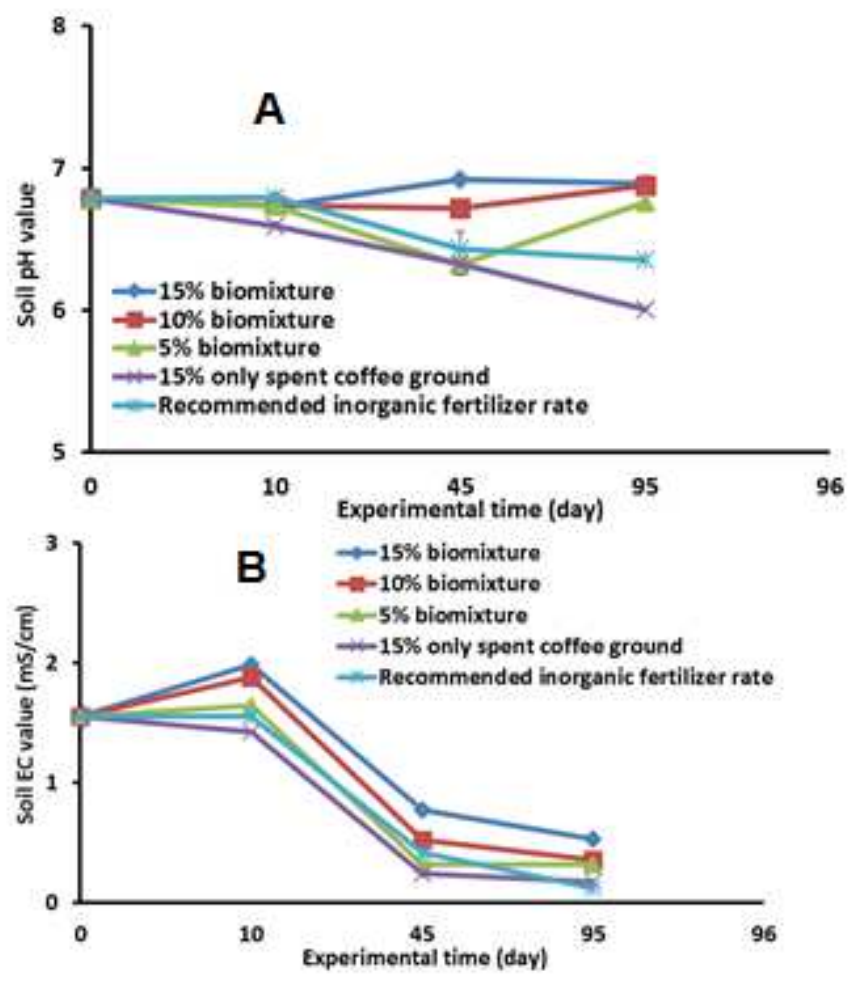

Fig.1. The fluctuations of soil pH (A) and EC (B) during the experimental time ( $\mathrm{n}=4$, standard deviation).

The soil used in this green house experiment study had low nutrients such as organic matter, total $\mathrm{N}, \mathrm{P}$ and $\mathrm{K}$ since it has been used for crop cultivation for over many seasons and many years. A comparison between soil chemical properties at the start of the experiment and at the end of the experiment was taken into account. The results showed that there was a tendency of a great increase for the soil organic matter and total nitrogen contents in all the treatments amended with biomixture containing spent coffee ground and egg-shells at the end of the experiment as compared to those in the beginning soil sample. They were highest in the treatment applying $15 \%$ coffee ground (T4) and were $5.14 \%$ and $0.62 \%$, respectively (Fig. 2A). For the control treatment (T5), the content of organic matter and total nitrogen were tendentially lowest as compared to other treatments and also lower than those of the beginning soil sample, accounting for $1,94 \%$ and $0,20 \%$, respectively (Fig. 2B). Meanwhile, the total phosphorus and potassium contents in all treatments measured at the end of the experiment did tendentially changed very little as compared to the soil sample taken at the beginning time of the experiment (Fig. 2C and 2D). This result indicated that when amended with spent coffee ground soil organic matter and total nitrogen contents are greatly enhanced, and the total phosphorus and potassium contents in the soil are also maintained. Consequently, there is no need to apply any chemical fertilizers for vegetables in the first season and spent coffee ground can help farmers in reducing the input costs and in improving of environmental pollution. Therefore, spent coffee ground may be a high 
quality organic fertilizer in near future to produce clean and organic vegetable products.
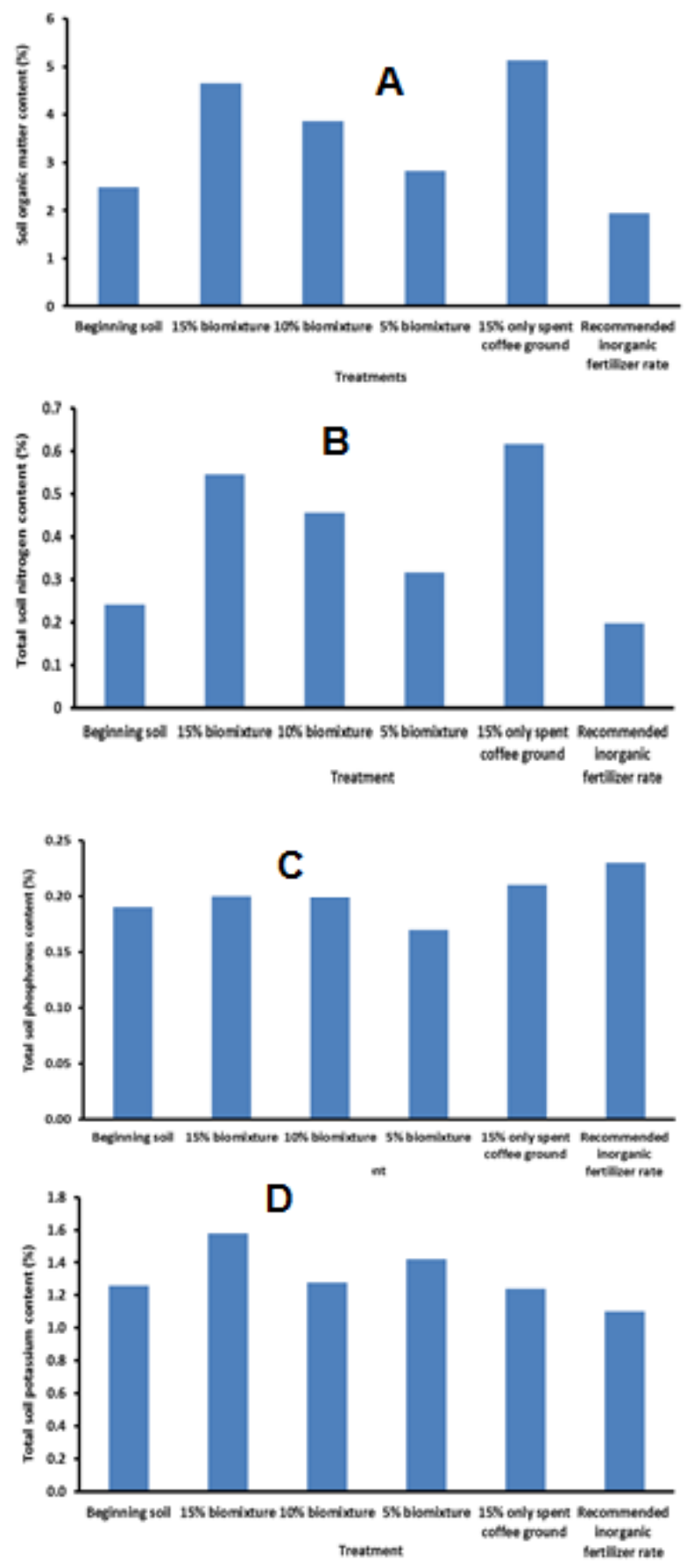

Fig.2. Some soil chemical properties at beginning and the the end of the experiment: soil organic matter content (A), total soil nitrogen content (B), total soil phosphorous content (C) and total soil potassium content (D).

\section{2) Soil Microorganisms}

The change of bacterial and fungal numbers in all treatments during experimental time was presented in Fig. 3. Bacterial and fungal cell counts in soils increased rapidly and reached the highest cell numbers at day 10 of the experiment. Then, afterwards their populations declined gradually until at the end of the experiment because of a competition for nutrinent among microorganisms and between microorganisms and crops as well. Bacterial and fungal cell counts of all treatments received an amendment of spent coffee ground treatments were significantly higher than those in the control treatment (T5) for almost all sampling times, especially at day 10 and 95 of the experiment (Fig. 3A and 3B). This result revealed that the efficacy of applying spent coffee ground and egg-shells on enhancement of the density of bacteria and fungi in the soil including even some beneficial microorganisms such as nitrogen fixing, phosphate solubilizing and IAA synthesizing bacteria stimulating the plant growth and development and ultimately crop yield increased.
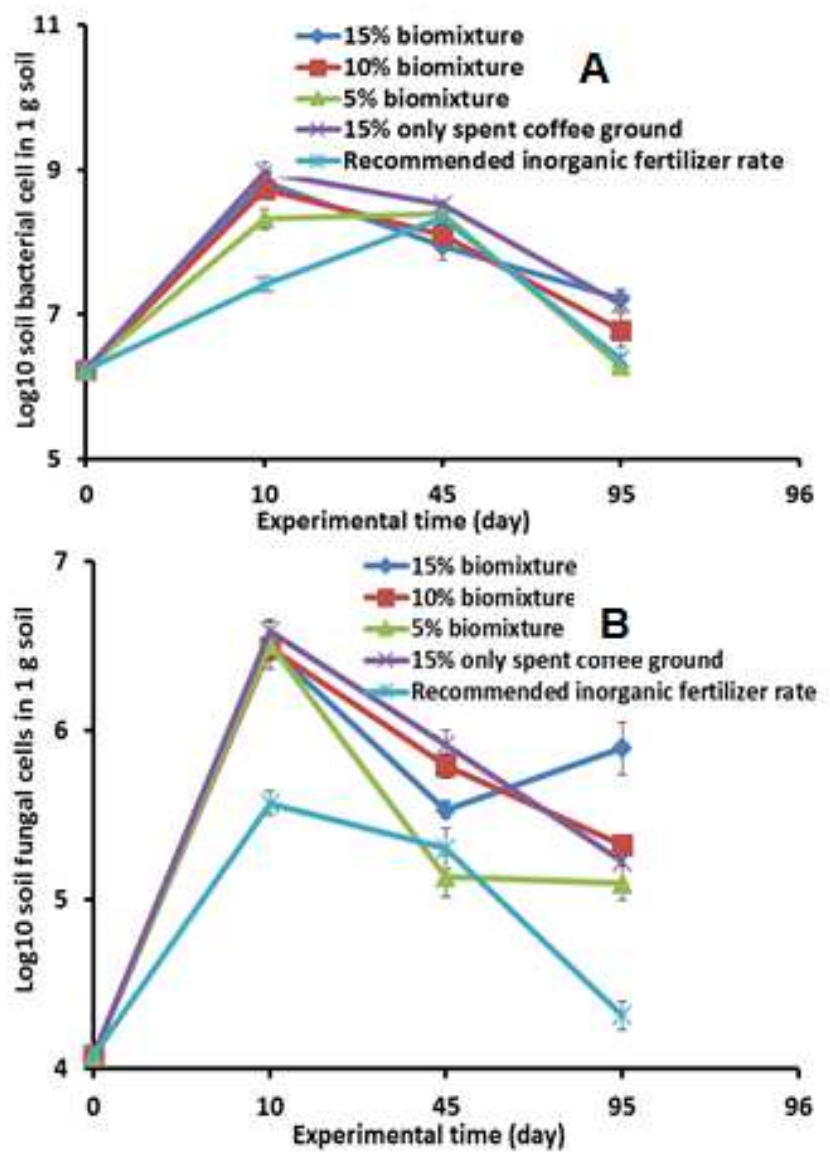

Fig.3. The fluctuations of bacterial (A) and fungal (B) cell numbers in soils during the experimental time ( $\mathrm{n}=4$, standard deviation).

\section{Effect of Applying Spent Coffee Ground and Egg-Shells on Okra Growth}

\section{1) Overview Observation}

At the seedling stage, Okra grew best in control treatment (T5) compared to other treatments amended with spent coffee ground and egg-shells and Okra's leaves in the T5 showed heavy green in color whereas these in the amended coffee ground treatments were between light green and slight yellow in color. This may be caused by the immobilization of available $\mathrm{N}$ by soil microorganisms after applying organic matter into the soil. The lowest growth of okra was found in the T4 (15\% spent coffee ground). However, from the middle growth stage until the end of the season, Okra's grow performance in all treatments amended with spent coffee ground were much better than in the control treatment (T5) 
through some following observed external characteristics: 1) Leave: in amended spent coffee ground treatments, Okra's leaves performed light green, shiny and very healthy in color. No nutrient deficiency and disease symptoms were found in these treatments while in the control treatment (T5) although okra's leaves were larger and thicker, but they were very stiff, rough, scabrous and unhealthy with many shown nutrient deficiency and disease symptoms; 2) Apical meristems: many healthy young leaves and flower buds. Flowers formed effective fruits which reached the standard quality level for selling and no insect was found in these treatments whereas in the control treatment, the apical meristems of okra were twisted. Young leaves and buds were stunted and very little flowers formed effective fruits for selling. This may be caused by plant nutrient deficiency in this soil as result of intensive cultivation without organic fertilizer application and 3) Okra fruit: in treatments amended with spent coffee ground the appearance of okra fruits were long, light green, smooth and shiny. They reached the quality for selling while okra fruits in the T5 (recommended inorganic fertilizer application rate) were attacked by many insects, curved, scabrous and did not reached the good quality for selling (Fig. 4). Therefore, coffee ground and egg-shells can be used directly and collectively as organic fertilizer to the soil to increase crop yield and to solve environmental problems and towards a clean, green and organic agriculture.

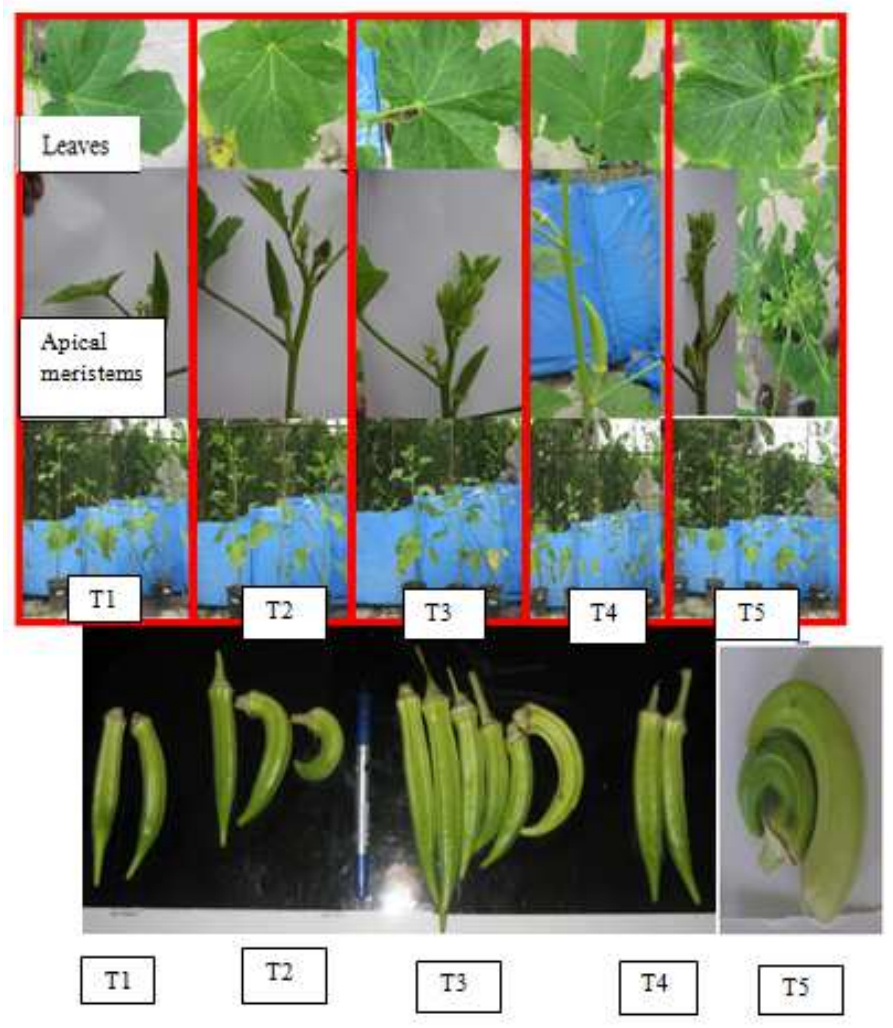

Fig.4. Overview observation on the grow performance of Okra between treatments including leaves, apical meristems and fruits.

\section{2) Plant Height, Number of Leaves per Plant and Stem} Diameter

Effect of experimental treatments to Okra growth were presented in Fig. 5. In general, plant height, number of leaves and stem diameter of Okra in control treatment were significantly higher than those in the treatments received both spent coffee ground and egg-shells application. Regardless of egg-shell application, the applied spent coffee ground treatments showed no statistical difference when compared to each other (Fig. 5A, 5B and 5C).
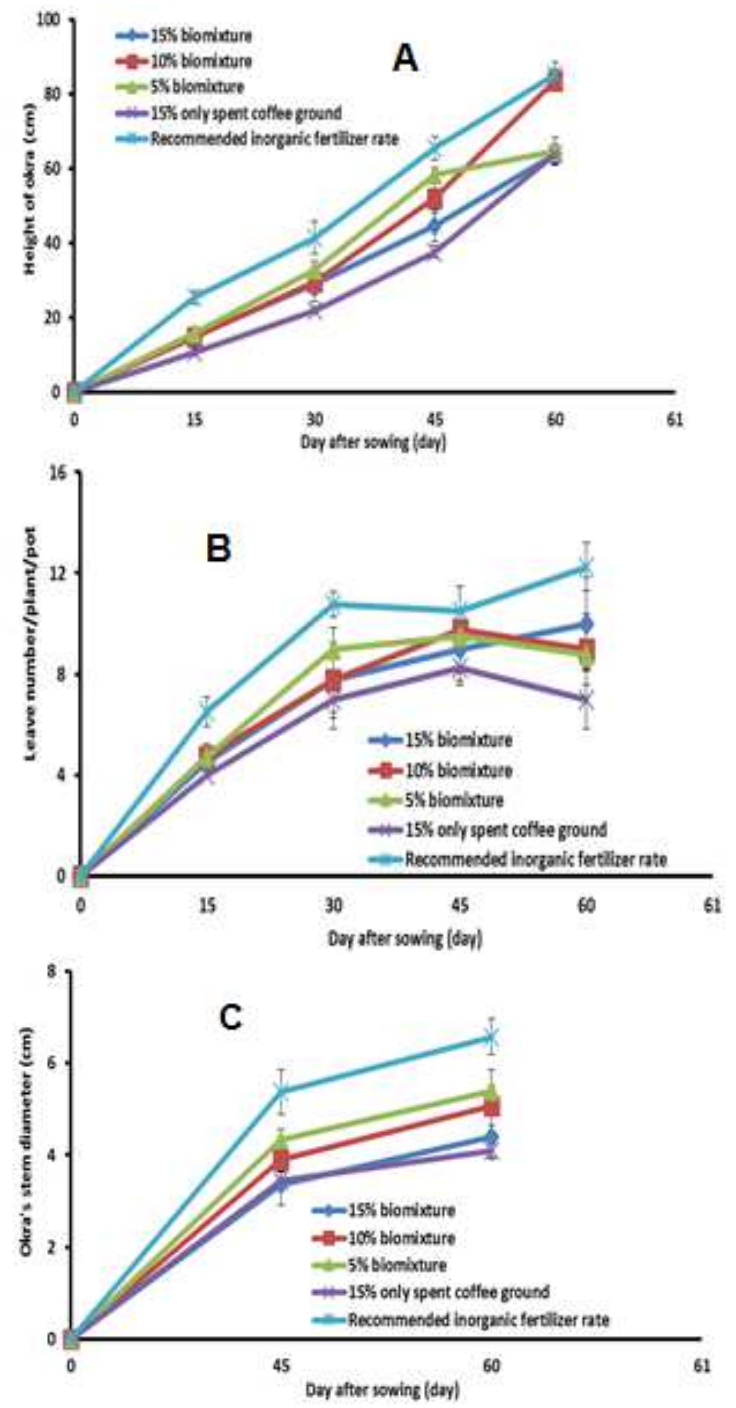

Fig. 5. Development and growth of okra during the experimental course: plant height (A), number of leaves per plant (B) and stem diameter (C).

At day 60 only the treatment 2 (T2, $10 \%$ biomixture application) showed no statistically significant difference with the T5 regarding of Okra plant height while other treatments showed their lower significant differences as compared to the T5 in regarding of plant height. Thus, obviously, the recommended inorganic fertilizer application rate treatment only helped in an increase of Okra plant biomass, but not in improving crop health and the tolerant ability under disadvantageous conditions of surrounding environments and pests. Meanwhile, applying a biomixture containing coffee ground and egg-shells did not help in an increase of Okra plant biomass, but improved crop health 
and the tolerant ability under hazardous conditions and pest attacks as well. This may be due to the spent coffee ground has many organic bioactive compounds helping in increasing of plant defencing ability under the adverse environmental stress conditions, especially for nutrients and pest [10].

\section{Effect of Biomixture Application Containing Spent Coffee Ground and Egg-Shells on Okra Yield}

Results of Okra yield harvested during the experimental time were shown in Fig. 6. The highest yield of Okra was found in the two treatments amended with 10 and $5 \%$ of the biomixture (T2 and T3) and was 167,07 and 161,02 $\mathrm{g} /$ plant/pot, respectively. They were significant difference at $5 \%$ of statistical level as compared to other treatments. Okra yield of the treatment 1 (amended with $15 \%$ biomixture) was $135,92 \mathrm{~g} / \mathrm{plant} /$ pot and lower than that of these above two treatments whereas both control treatment (T5) and 15\% only spent coffee ground (T4) had the lowest yield and were 36,05 and 44,50 g/plant/pot, respectively. When taking into account to compare the Okra yield between T1 (15\% biomixture) and T4 (15\% only spent coffee ground), the results showed that the okra yield in the treatment 1 was $161,02 \mathrm{~g} /$ plant/pot) and much higher than that in the treatment 4 (44,50 g/plant/pot).

Obviously, this result indicated for an important role of egg-shells in an interaction with spent coffee ground to increase the okra yield. This may be caused by the fact that egg-shells may contain a large amount of essential secondary nutrients and micronutrients supporting for microorganisms and plant growth, such as: $\mathrm{Ca}, \mathrm{Mg}, \mathrm{Bo}, \mathrm{Cu}$, $\mathrm{Fe}, \mathrm{Mn}, \mathrm{Mo}$ and S [15] while spent coffee ground has a large amount of only macronutrients such as: N, P, K. Moreover, egg-shells also played a role as lime function to maintain neutral level of soil pH for plant to grow well (Fig. 1) and to control some plant phathogens in the soil. These above facts were proven in section 3.3.1. Thus, when combining these two materials (spent coffee ground and milled egg-shells), essential nutrients for plants and microorganisms became better and optimal and so okra yield was increased. Amendment of this biomixture into soil helped to increase Okra yield much more than that in the recommended inorganic fertilizer application rate treatment (T5) and T4 (only spent coffee ground applied) as well. The enhancement of okra fruit yield as a result from a maintenance of soil $\mathrm{pH}$, an increase of soil organic matter and total nitrogen contents and an increase of soil bacterial and fungal populations when soil was amended with this biomixture.

These facts leaded Okra to grow healthier and to increase the tolerant ability of okra in facing to adverse surrounding environmental conditions. In short, application rare of $5 \%$ biomixture containing spent coffee ground and egg-shells with a mixing ratio of $10: 2$, respectively was the most suitable treatment among investigated treatments in this study to enhance the Okra yield under the green house conditions.

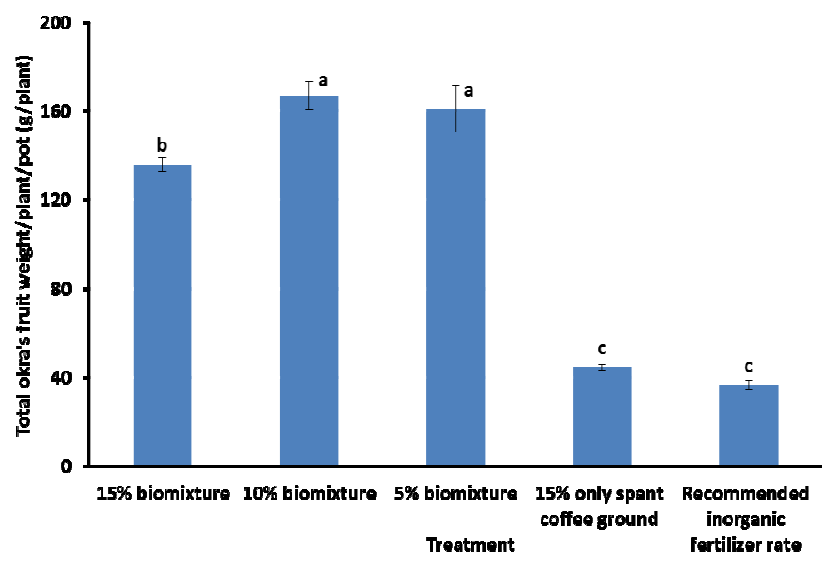

Fig. 6. Total effective fruits weight of okra in treatments during the experimental time $(n=4$, standard deviation).

\section{CONCLUSIONS}

Spent coffee ground and egg-shells could be used directly as a kind of organic fertilizer for Okra without adding any chemical fertilizers in the first season. Application of the biomixture containing spent coffee ground and milled eggshells (ratio of 10:2, respectively based on dry weight) into soil helps to increase soil nutrients, soil health and Okra yield. The biomixture of coffee ground and milled eggshells maintained soil $\mathrm{pH}$, increased soil organic matter, total soil nitrogen and soil bacteria and fungi numbers. It could make crops become healthier and more tolerant to disadvantageous environmental conditions such as nutrient deficiency and plant insects and pathogen. Ultimately, Okra yield would increase. Addition of $15 \%$ only spent coffee ground and $15 \%$ biomixture into soil did not cause any phytotoxicity for okra. Application are of 5\% biomixture containing spent coffee ground and egg-shells was the optimal dose to enhance Okra health and yield as compared to others. A biomixture of spent coffee ground and eggshells has a great application potential in development of organic and sustainable agriculture.

\section{REFERENCES}

[1] Tam ThanhTran, 2013. Vietnam's coffee industry. Ipsso business consulting.

[2] Pelupessy. W, 2003. Environmental issues in the production of beverages: global coffee chain. In: Mattsson B, Sonesson U (eds). Environmentally-friendly food processing. Woodhead Publishing Limited, Cambridge, pp 95-115.

[3] Ivo, S; Katerina, H; Barbora, S; Mirka, S, 2012. Magnetically modified spent coffee grounds for dyes removal. Eur. Food Res. Technol. 234: 345-350.

[4] Nguyen Van Dat, Bui Thi Buu Hue, Do Vo Anh Khoa, Le Thi Bach, Ngo Thi Kim Lien, Pham Be Nhi, Ha Thi Kim Quy, Hoang Thi Mai Lan, 2011. Synthesis of biodiesel from spent coffee ground. Cantho University Scientific Journal. 20b: 248-255.

[5] Silva, M.A; Nebra, S.A; Silva, M.J.M; Sanchez, C.G, 1998. The use of biomass residues in the Brazilian soluble coffee industry. Biomass Bioenerg. 14: 457-467.

[6] Le Hong Phu, Nguyen Duc Luong, Do Dai Nghia, 2008. Study of producing biocoffee-1 by-product from Aspergillus niger and it's fermentation application for other coffees. Journal of Science and Technoloty Development. 11 (12). 
[7] Chu Thi Bich Phuong, Nguyen Thi Trung Uyen, Huynh Phuong Thanh, Pham Van Loc, Bui Van The Vinh, Nguyen Cong Hao, 2012. Study of method to extract biodiesel from spent coffee ground and use of this waste as substrate for Lingzhi mushroom (Ganoderma lucidum). Journal of Vietnam Biology. 34 (3SE): 69-77.

[8] Tokimoto, T; Kawasaki, N; Nakamura, T; Akutagawa, J; Tanada, S, 2005. Removal of lead ions in drinking water by coffee grounds as vegetable biomass. J Colloid. Interface. Sci. 281: 56-61.

[9] Adi, A.J; Noor, Z.M, 2009. Waste recycling: utilization of coffee grounds and kitchen waste in vermicomposting. Bioresour. Technol. 100: 1027-1030.

[10] Teresa, G; Jose, A.P; Elsa, R; Susana, C; Paula, B, 2013a. Effect of fresh spent coffee grounds on the oxidative stress and antioxidant response in lettuce plants. Congress of Agriculture and Horiculture, Marid, Spain, 26-29, 2013.
[11] Teresa, G; Jose, A.P; Elsa, R; Susana, C; Paula, B, 2013b. Effect of fresh and composted spent coffee grounds on lettuce growth, photosynthetic pigments and mineral composition. http://hdl.handle.net/10198/8719.

[12] Holmes, J. D; Sawyer, J. E; Kassel, P; Ruiz Diaz, D, 2011. Using ground eggshells as a liming material in corn and soybean production. Crop Management, doi:10.1094/CM-2011-1129-01-RS.

[13] Ian, L.P; Charles, P.G, 2004. Environmental Microbiology: A laboratory manual. ISBN 13: 978025505664.

[14] Duong Minh Vien, Tran Kim Tinh, Vo Thi Guong, 2011. Compost fertilizer production and efficacy of compost on crop yield improvement and soil quality. The Vietnam argiculture publish house.

[15] King'ori, A.M., 2011. A Review of the Uses of Poultry Eggshells and Shell Membranes. International Journal of Poultry Science. 10 (11): 908-912. 